\title{
GnRH agonists and the rapidly increasing use of combined androgen blockade in prostate cancer
}

\author{
Fernand Labrie
}

2795 Laurier Boulevard, Suite 500, Quebec City, Quebec, Canada G1V 4M7

\author{
Correspondence \\ should be addressed \\ to F Labrie \\ Email \\ flabrie@attglobal.net
}

\begin{abstract}
The discovery of medical castration with GnRH agonists in 1979 rapidly replaced surgical castration and high doses of estrogens for the treatment of prostate cancer. Soon afterwards, it was discovered that androgens were made locally in the prostate from the inactive precursor DHEA of adrenal origin, a mechanism called intracrinology. Taking into account these novel facts, combined androgen blockade (CAB) using a pure antiandrogen combined with castration in order to block the two sources of androgens was first published in 1982. $C A B$ was the first treatment shown in randomized and placebo-controlled trials to prolong life in prostate cancer, even at the metastatic stage. Most importantly, the results recently obtained with the novel pure antiandrogen enzalutamide as well as with abiraterone, an inhibitor of $17 \alpha$-hydroxylase in castration-resistant prostate cancer, has revitalized the $C A B$ concept. The effects of $C A B$ observed on survival of heavily pretreated patients further demonstrates the importance of the androgens made locally in the prostate and are a strong motivation to apply $C A B$ to efficiently block all sources of androgens earlier at start of treatment and, even better, before metastasis occurs. The future of research in this field thus seems to be centered on the development of more potent blockers of androgens formation and action in order to obtain better results at the metastatic stage and, for the localized stage, reduce the duration of treatment required to achieve complete apoptosis and control of prostate cancer proliferation before it reaches the metastatic or noncurable stage.
\end{abstract}

\section{Key Words}

- GnRH agonists

- intracrinology

- combined androgen blockade

- castration-resistant prostate cancer

- antiandrogens

- inhibitors of steroidogenesis

\section{Introduction}

Prostate cancer is the most frequently diagnosed cancer and the second cause of cancer death in men in North America (Siegel et al. 2013). In fact, one in eight men will be diagnosed with prostate cancer during his lifetime. At such a rate, more than 3000000 men will die from prostate cancer among the male population presently living in the
United States, whereas more than 250000 die annually worldwide from prostate cancer (Jemal et al. 2011). The very serious medical and social consequences of this disease are comparable to those of breast cancer in women.

Although improvements in surgery and radiotherapy have occurred, a study reported by Lichtenberg (2002) 
using National Cancer Institute data from 2.1 million patients with cancer in the USA from 1975 to 1995 concluded that 'cancer-fighting drugs improved survival rates, especially for cancer of the prostate, where drug innovations have been the greatest'. The drug innovations in the field of prostate cancer have been gonadotropinreleasing hormone (GnRH) agonists (Labrie et al. 1980, 1996, 2005a) used to achieve medical castration and the pure antiandrogens or compounds having exclusive antagonistic activity at the androgen receptor (AR) (Neri et al. 1967, El Etreby et al. 1987, Furr et al. 1987) administered in association with medical or surgical castration (Labrie et al. 1982, 1985, Crawford et al. 1989, Labrie 2007). The combination of castration with a pure antiandrogen has been called combined androgen blockade (CAB).

Androgen blockade is the standard of care for advanced prostate cancer (Crawford 2009, Labrie 2011a), while the benefits of chemotherapy or immunotherapy are accompanied with more important side effects and are usually used at a later stage of the disease (Tannock et al. 2004, Eisenberger \& Sinibaldi 2006, Kantoff et al. 2010).

It should be considered that despite the significant improvements in diagnosis and treatment, prostate cancer remains the second most common cause of death after lung cancer in American men. There is thus the need for potentially more potent, specific and well tolerated agents which can provide a longer and good quality of life while avoiding the morbidity associated with the progression of prostate cancer (Garcia \& Rini 2012).

After briefly mentioning the current status of knowledge on the endocrinology/intracrinology of the prostate, this review will briefly summarize the data obtained after monotherapy (castration alone) and CAB given as first-line therapy at different stages of the disease. With regard to castration-resistant prostate cancer (CRPC), which is currently the main target of recent prostate cancer research, this review will refer to the proposed mechanisms of resistance to endocrine therapy and highlight the clinical observations which demonstrate that prostate cancer continues to respond to other forms of androgen blockade after development of resistance to blockade of testicular androgens, thus illustrating the major importance of extratesticular androgens made locally by the mechanisms of intracrinology.

The revival of the interest for CAB stems largely from the very encouraging clinical data obtained with a novel blocker of the AR (MDV-3100) and with an inhibitor of androgen formation (abiraterone) in CRPC patients. Extrapolation will then be made on potential future developments in the field of androgen blockade and prostate cancer therapy. It should be remembered that prostate cancer is the most sensitive of all cancers to hormone therapy. Consequently, it is logical that every effort should be made to take advantage of this unique characteristic (Labrie 2011b).

\section{Discovery of medical castration with GnRH agonists and its impact}

More than 3 decades ago, when experimental animals were treated for a few days with a GnRH super-agonist, an increase in the weight of the seminal vesicles and prostate was expected. Unexpectedly, the opposite effect was observed: the prostate, seminal vesicles and testicles all became smaller after a few days of treatment (Auclair et al. 1977a, b, Pelletier et al. 1978).

Although experiments in rats did suggest that GnRH agonists had partial inhibitory effect on testicular function, we discovered that chronic administration of GnRH agonists achieves medical castration in men who appear to be the most sensitive of all species to the inhibitory effects of GnRH agonists on testicular androgen secretion. In fact, when we first administered a GnRH agonist to a patient with stage B prostate cancer, a $70-85 \%$ reduction in the serum levels of testosterone and dihydrotestosterone (DHT), respectively, occurred as early as 2 weeks after the start of therapy (Labrie et al. 1980; Fig. 1). The GnRH agonist used was buserelin at a dose of $500 \mu \mathrm{g}$ given intranasally. Shortly afterwards, when the effects of various doses of buserelin administered intranasally and subcutaneously were compared in detail, results showed that the s.c. route should be preferred (Faure et al. 1982). Thirty-three years ago the first prostate cancer patient was treated with a GnRH agonist at the Laval University Medical Center in Quebec City, Canada, thus rapidly leading to the worldwide replacement of surgical castration and high doses of estrogens with GnRH agonists. The discovery of medical castration with GnRH agonists rapidly led to fundamental changes in the endocrine therapy of prostate cancer.

Medical castration with GnRH agonists was a somewhat a unique discovery in medicine since, for the first time, a completely unexpected inhibitory effect on testicular function was observed using a stimulatory molecule (GnRH agonist). The mechanism responsible for the castration effect of GnRH agonists is the loss of biological activity of luteinizing hormone (LH) during long-term treatment with GnRH agonists (St-Arnaud et al. 1986). According to the then current knowledge, a potent

Published by Bioscientifica Ltd. 


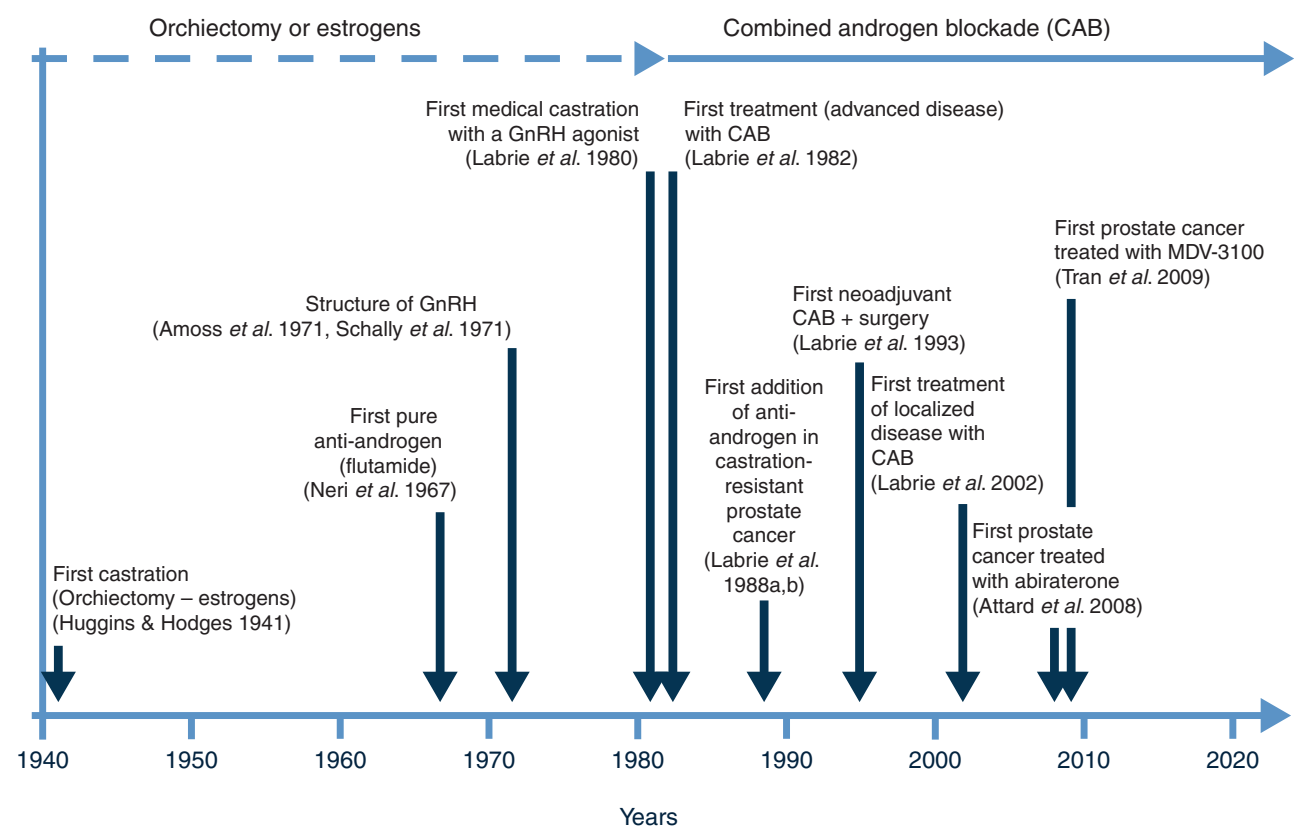

Figure 1

Landmarks in the development of androgen blockade in prostate cancer.

GnRH agonist should have resulted in long-term and potent stimulation of testicular functions. This innovative therapy is particularly important for patients with localized or locally advanced prostate cancer who need a treatment for long-term use. Accordingly, GnRH agonists were rapidly adopted worldwide to achieve medical castration (Labrie et al. 2005a, Labrie 2007). The major medical importance of this discovery is indicated by worldwide annual sales of the order of US\$ 3.0 billion during the last 25 years. GnRH antagonists have been developed to achieve comparable inhibitory effects on testosterone secretion by the testicles.

\section{Effect of castration on localized or locally advanced disease}

Most importantly, the excellent tolerance observed with GnRH agonists has permitted a series of studies in localized/locally advanced disease which have shown a major reduction in the death rate due to prostate cancer, ranging, in the early studies, from 31 to $87 \%$ at 5 years of follow-up (see Labrie et al. (2005a) for review) (Labrie et al. 2005a). A meta-analysis that combined data from several studies involving $\sim 5000$ men concluded that the risk of dying from prostate cancer within 10 years decreased by one third if blockade of testicular testosterone secretion was started immediately after diagnosis of localized or locally advanced disease rather than once the disease had progressed (Arnst 2003, Peto \& Dalesio 2003). These data led (Peto \& Dalesio 2003) to the conclusion that 'hormone treatment as a whole works much better than previously thought'. It should be remembered, however, that these results were obtained by blockade limited to testicular androgens. As indicated later, only $60-75 \%$ of total androgens present in the prostate were eliminated (Labrie et al. 2009). Knowing, as discussed later, the multiple sources of prostatic androgens, it is not surprising to believe that optimal treatment requires a combination of therapeutic agents or $\mathrm{CAB}$ at minimum.

\section{Two sources of androgens are active in the human prostate: intracrinology}

Humans and other primates are unique in having adrenals that secrete large amounts of the inactive precursor steroids DHEA and DHEA-S, which are converted into potent androgens in many peripheral tissues, including the prostate (Fig. 2). In adult men, the plasma concentration of DHEA-S secreted by the adrenals is 100-500 times as high as that of testosterone, the main secretory product of the testes (Labrie et al. 1985, 2005a). Therefore, there are large circulating amounts of the precursors required for the production of active androgens in the prostate and other peripheral intracrine tissues (Fig. 3).

A particularly remarkable and highly sophisticated achievement of evolution is intracrinology, the

Published by Bioscientifica Ltd. 


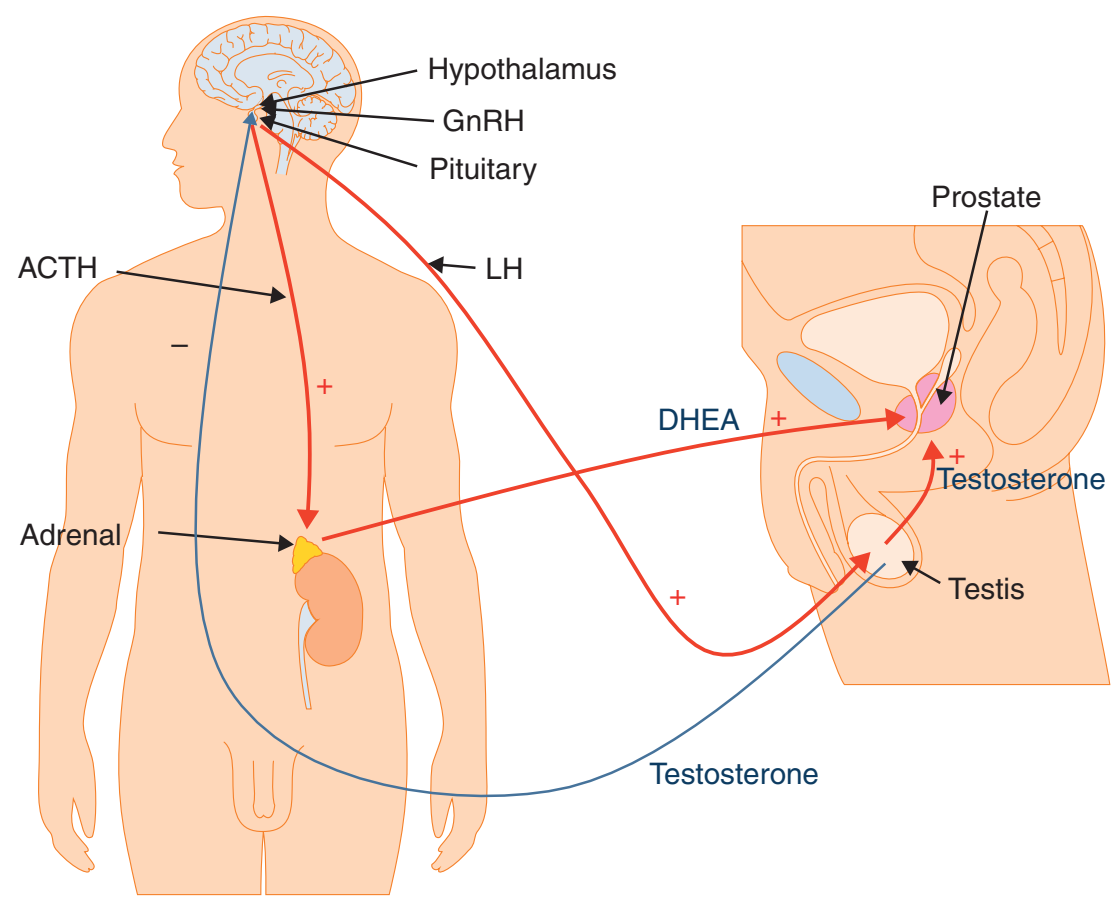

\section{Figure 2}

Sources of androgens in the human prostate. Hypothalamic GnRH stimulates the release of LH from the anterior pituitary. LH, in turn, stimulates the Leydig cells of the testes to produce testosterone, which is released into the bloodstream. Pituitary ACTH stimulates glucocorticoid and DHEA secretion from the adrenal glands. DHEA is converted into

mechanism that permits specific and local production of sex steroids for a strictly local action without significant release of active sex steroids in the circulation. In 1988 this mechanism was named as intracrinology (Labrie et al. 1988a) following observations made in the early 1980s in men castrated for prostate cancer (Labrie et al. 1985) which showed that an important proportion of the androgens present in the human prostate is made from the DHEA present in the prostate itself.

Through an estimated period of 500 million years (Baker 2004), evolution has progressively provided the peripheral tissues with the enzymes able to make and inactivate sex steroids locally (Fig. 3). However, it is only about 50 million years ago that the ability to secrete large amounts of the precursor substrate, DHEA, appeared in the adrenals of primates. Very recently, the transformation of DHEA into estrogens and/or androgens by the mechanisms of intracrinology has been demonstrated (Labrie et al. 1985, 1988a, 1989, 2005b, Labrie 1991, 2010a, Luu-The 2011; Figs 3 and 4).

It is very important to mention that an essential aspect of intracrinology is that the active sex steroids are testosterone and then into DHT and some estrogens in the prostate. Each of the two pathways (testis and adrenal) provides comparable amounts of androgens. ACTH, adrenocorticotropin; DHT, dihydrotestosterone; $\mathrm{GnRH}$, gonadotropin-releasing hormone; $\mathrm{LH}$, luteinizing hormone.

not only made locally but also inactivated locally at the same site where synthesis takes place (Bélanger et al. 2003; Fig. 4). In fact, the sex steroids made from DHEA in peripheral tissues are essentially released outside the cells as inactive compounds. (Labrie et al. 2009, Olsson et al. 2010).

As illustrated in Fig. 4, DHEA of adrenal origin is distributed by the general circulation to all tissues indiscriminately. The transformation of DHEA into estrogens/androgens, however, is tissue-specific, ranging from none in the endometrium to various levels in the other tissues of the human body. Most importantly, $\sim 95 \%$ of the active estrogens and androgens are inactivated locally before being released into the blood as inactive metabolites, thus avoiding inappropriate exposure of the other tissues (Labrie 2010a; Fig. 4). The local intracellular inactivation of testosterone and DHT explains why only a very small fraction of the active androgens (and estrogens) secreted intracellularly are manifested in the blood stream (Figs 4 and 5A). In fact, serum levels of testosterone are reduced by $97 \%$ following castration in men aged between 69 and 80 years (Fig. 5; Labrie et al. 2009).

Published by Bioscientifica Ltd 


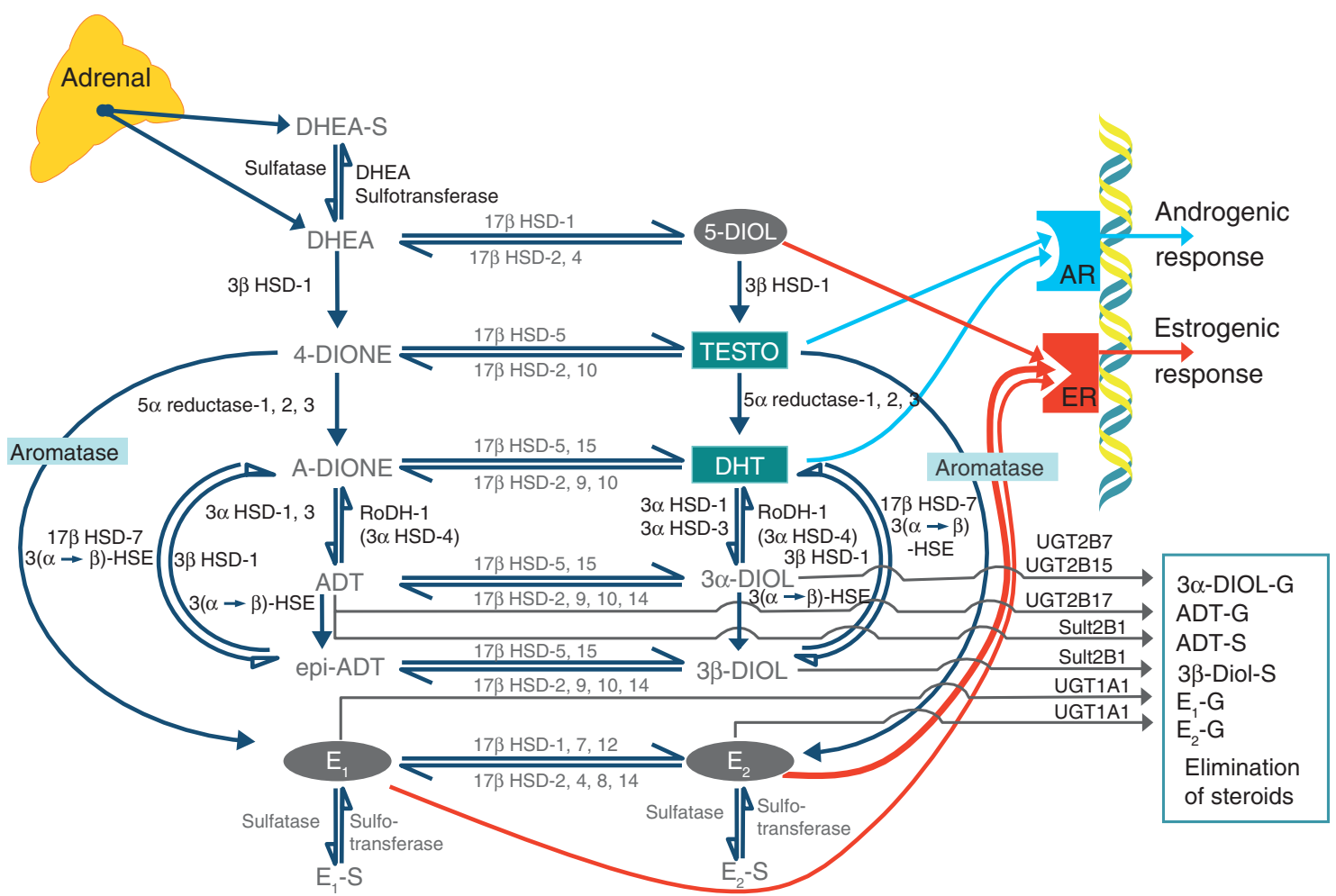

\section{Figure 3}

Human steroidogenic and steroid-inactivating enzymes in peripheral intracrine tissues: 4-dione, androstenedione; A-dione, 5 - $\alpha$-androstane-3, 17-dione; $A D T$, androsterone; epi-ADT, epiandrosterone; $E_{1}$, estrone; $E_{1}-S$, estrone sulfate; $E_{2}, 17 \beta$-estradiol; $E_{2}-S$, estradiol sulfate; 5 -diol,

The contribution of adrenal DHEA to total androgen levels is best illustrated by the concentration of the serum androgen metabolites remaining in the blood stream and by the concentration of intraprostatic DHT (the most potent naturally occurring androgen) remaining in the prostate, after castration (Labrie et al. 1985, 2009, Bélanger et al. 1989, Labrie 2008, 2010b; Fig. 5). The sum of the concentrations of androgen metabolites (the total androgen pool) is the only accurate method for measuring total androgenic activity in the circulation (Labrie et al. 2006). This sum of androgen metabolites is only reduced by about $60 \%$ after castration (Fig. 5). Such findings indicate that about $40 \%$ of total androgens in the prostate are made locally and thus remain in the prostate and free to stimulate prostate cancer after elimination of testicular androgens. These data are in close agreement with the measurements of intraprostatic DHT concentrations by different laboratories. These data show that, globally, the concentration of DHT measured in the prostate after castration approximately ranges from 20 to $50 \%$ of that measured in intact men (Fig. 5; Labrie et al. 1985, Bélanger et al. 1989, Nishiyama et al. 2004, Mostaghel et al. 2007). androst-5-ene-3 $\alpha$, 17 $\beta$-diol; HSD, hydroxysteroid dehydrogenase; testo, testosterone; RoDH-1, Ro dehydrogenase 1; $A R$, androgen receptor; $E R$, estrogen receptor; UGT2B28, uridine glucuronosyl transferase 2B28; Sult2B1, sulfotransferase $2 \mathrm{~B} 1$; UGT1A1, uridine glucuronosyl transferase 1A1.

Another study has shown that intraprostatic DHT levels remained at $50 \%$ of intact values after castration (Yoon et al. 2008).

\section{Combined androgen blockade}

\section{A clear distinction must be made between monotherapy and $C A B$}

Once the presence of two sources of androgens stimulating prostate cancer is known, it is important to use a precise terminology to be able to discriminate between the different sources of androgens which need different interventions to be controlled. In this context, androgen deprivation therapy (ADT) is an imprecise terminology which does not permit the identification of different treatment modalities having different efficacies. For example, 'surgical or chemical castration' should not simply be called 'ADT' because it does not discriminate between very different sources and blockages of androgens. The exact situation is rather the following: 'surgical or chemical castration has been the treatment of choice

Published by Bioscientifica Ltd. 


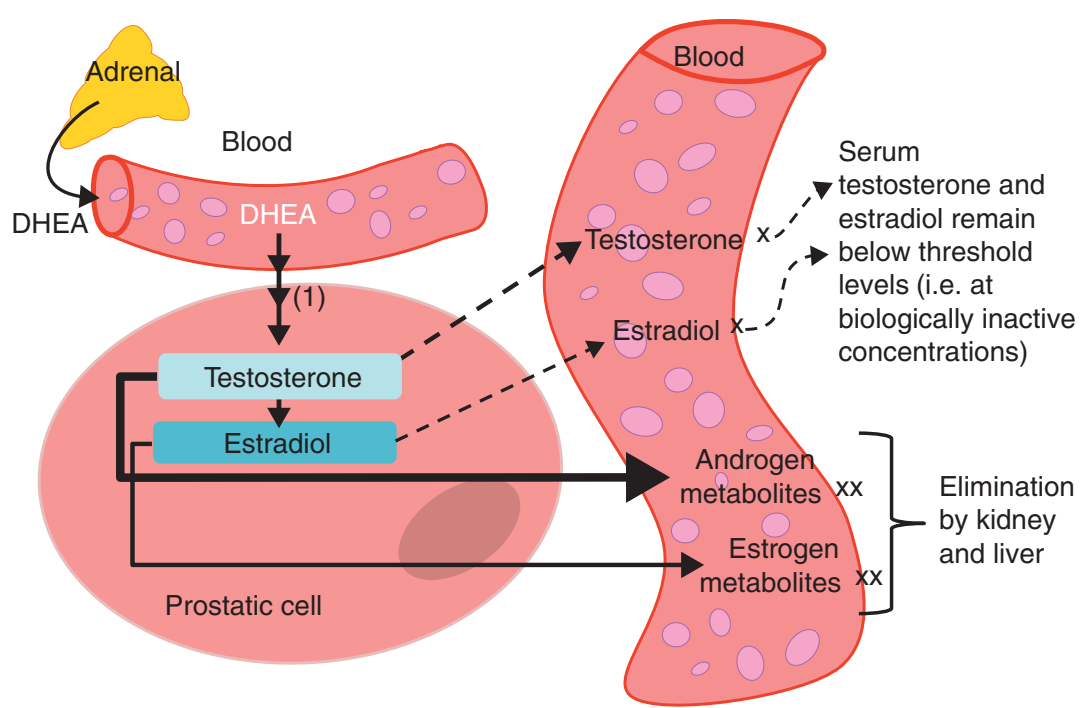

$X$, very low subthreshold or biologically inactive levels in blood; do not exert significant systemic biological activity

$\mathrm{XX}, 95 \%$ or more eliminated as inactive metabolites

(1) Labrie 1991 Molecular and Cellular Endocrinology 78, C113-C116. Labrie, Luu-The et al. 2005 Journal of Endocrinology 187, 169-196. Labrie, Martel et al. 2011 Menopause 18, 30-43.

\section{Figure 4}

Schematic representation of the mechanisms of intracrinology: DHEA of adrenal origin is transported by the circulation to all peripheral tissues where it is transformed into cell-specific concentrations and ratios of testosterone and/or estradiol, depending upon the cell-specific pattern and level of expression of the steroid-forming and steroid-inactivating enzymes. Testosterone and estradiol are $95 \%$ or more inactivated locally, with a very small amount of active sex steroids diffusing into the blood where they are present at subthreshold or biologically inactive

for patients with advanced disease for the past 70 years'. As will be discussed later, ADT is not the synonym of surgical or chemical castration; the term ADT can also cover, among other possibilities, $\mathrm{CAB}$, which is very different from castration alone.

\section{Distinction must be made between localized and metastatic disease}

The stage of the disease is an extremely important but an often neglected variable. A generalized and scientifically incorrect situation is to use conclusions obtained in metastatic prostate cancer and apply them to localized disease. The following is an example: 'prostate cancer is a disease that initially responds but later becomes resistant to androgen blockade' (Scher et al. 2012). As discussed in more detail later, this statement essentially comes from metastatic disease but is not appropriate for localized disease of which cure can be obtained with CAB (Labrie et al. 2002, Akaza 2006, Akaza et al. 2006a). Similarly, it concentrations, thus avoiding systemic effects in the other tissues, a condition necessary in postmenopausal women to avoid stimulation of the endometrium (Labrie \& Labrie 2013). The inactive metabolites of testosterone and estradiol, especially glucuronides and sulfates, are released into the blood from which they are removed by the kidneys and liver. In fact, comparable serum sex steroid levels are observed in castrated men and postmenopausal women (Labrie et al. 2011).

cannot be said 'All patients ultimately progress to metastatic CRPC' (Fizazi et al. 2012). This sentence is correct for patients first treated by castration at the metastatic stage, but it does not apply for $\mathrm{CAB}$ treatment at the localized stage of which cure is a possibility and progression is an exception (Labrie et al. 2002, Akaza et al. 2004, 2006a, Egawa et al. 2004, Homma et al. 2004, Akaza 2006, Ueno et al. 2006).

\section{Treatment of metastatic disease}

It is important to mention that no study has shown that medical or surgical castration alone had a statistically significant effect on survival in patients with metastatic prostate cancer. The data obtained for the first patients treated with $\mathrm{CAB}$ were published in 1982 (Labrie et al. 1982), thus leading to a series of randomized placebocontrolled studies, the first one being reported by Crawford et al. (1989), who showed statistically significant benefits on survival (Crawford et al. 1989). In fact, the 
A

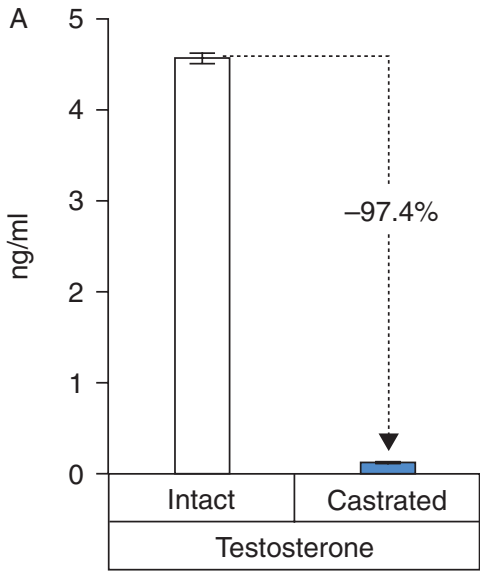

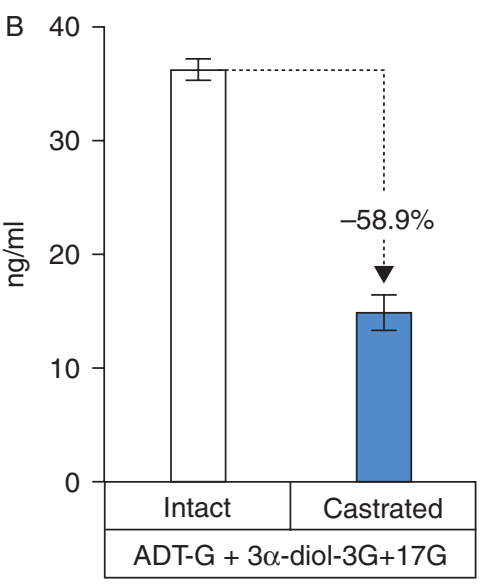

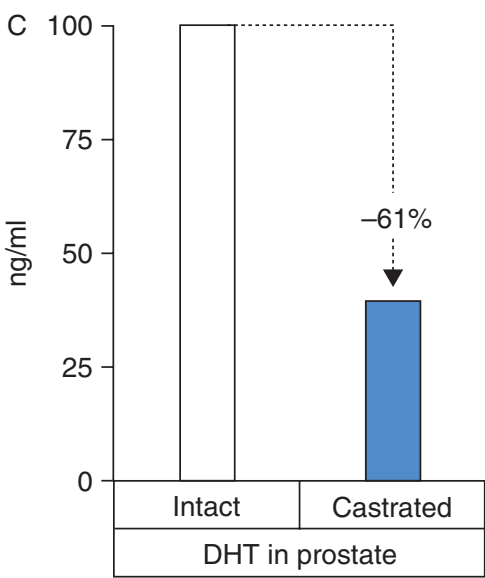

Labrie et al. 2009 Journal of Steroid Biochemistry and Molecular Biology 113, 52-56.

\section{Figure 5}

Effect of castration on serum androgen levels. (A) Castration reduces serum testosterone levels by $97 \%$. (B) The total androgen pool (the sum of the androgen metabolites androsterone glucuronide, androstane- $3 \alpha$-diol-3G and androstane- $3 \alpha$-diol-17G) remains high at $\sim 40 \%$ of the levels observed

combination of a pure antiandrogen (flutamide) with a GnRH agonist was the first treatment shown to prolong life in patients with advanced prostate cancer (Labrie et al. 1982, Crawford et al. 1989).

All clinical trials in patients with advanced prostate cancer have shown that $\mathrm{CAB}$ has some significant advantages over castration alone. These advantages include a higher proportion of patients with complete and partial responses, improved control of pain associated with metastatic disease, longer disease-free survival, and longer overall survival (Crawford et al. 1989, Caubet et al. 1997, Denis et al. 1998, Bennett et al. 1999, Prostate Cancer Triallists' Collaborative Group 2000). A large-scale study comparing castration + flutamide as the initial treatment compared with castration alone at start of treatment but with flutamide added later (when the cancer progressed despite castration) (Eisenberger et al. 1998) did not show a statistically significant effect of CAB $(P=0.14)$. This study was practically uninamously interpreted as showing no benefit while the data indicate an $86 \%$ likelihood that $\mathrm{CAB}$ administered at the start of treatment is superior on overall survival to administering flutamide later at time of relapse. It should also be mentioned that the abovementioned study, like all the other clinical trials, did not compare $\mathrm{CAB}$ with castration alone but $\mathrm{CAB}$ with the addition of flutamide (or other androgen blocker) at time of progression after castration, an approach which has been found early to induce a positive response in $34.2 \%$ of patients progressing after castration (Labrie et al. 1988b). in intact men. (C) Intraprostatic levels of dihydrotestosterone, the predominant androgen in the prostate, also remains at about $40 \%$ of the levels observed in intact men, an observation which indicates that the $\sim 40 \%$ remaining DHT after castration has an extratesticular origin.

$\mathrm{CAB}$ as a first-line treatment in metastatic disease increases overall survival by an average of 3-6 months compared with combined treatment with the antiandrogen started later (Crawford et al. 1989, Caubet et al. 1997, Denis et al. 1998, Bennett et al. 1999, Prostate Cancer Triallists' Collaborative Group 2000). Assuming that about half of these patients die from causes other than prostate cancer, this prolongation of life corresponds to an actual increase in life duration of 6-12 months when only prostate cancer is considered as cause of death.

While $\mathrm{CAB}$, as mentioned above, has many advantages on quality of life (including rapid response, decrease in pain, and survival) (Crawford et al. 1989, Caubet et al. 1997, Denis et al. 1998, Bennett et al. 1999, Prostate Cancer Triallists' Collaborative Group 2000), the costs are higher than other treatment options and some data suggest the possibility of negative cardiovascular effects (Levine et al. 2010) which need to be further investigated and balanced with the benefits mentioned earlier (Labrie et al. 2002, Akaza et al. 2004, 2006a, b, Egawa et al. 2004, Homma et al. 2004, Akaza 2006, 2008, Ueno et al. 2006, Namiki et al. 2008).

\section{Localized/locally advanced disease}

Considering the increasing aggressiveness and genetic abnormality of cancer in progression, it is logical to believe that improved or much improved results should be obtained if $\mathrm{CAB}$ is started when the cancer is limited to

Published by Bioscientifica Ltd. 
the prostate (localized) or is limited to the pelvic area (locally advanced) before the distant metastatic or irreversible stage occurs. Early data have indicated that the benefits of $\mathrm{CAB}$ are greater for patients with minimal metastatic disease than for those with extensive metastatic disease (Crawford et al. 1989, Denis et al. 1998). Similarly, in a study of 205 patients with stage C/D disease, at 5.2 years of follow-up, there was an advantage of $\mathrm{CAB}(\mathrm{GnRH}$ agonist $+80 \mathrm{mg}$ bicalutamide) over a GnRH agonist alone for overall survival ( $P=0.04$ ) (Akaza et al. 2009). The effect on cancer-specific death had not reached statistical significance $(P=0.09)$. These data support those of other studies which investigated $\mathrm{CAB}$ for treatment of stage $\mathrm{C}$ prostate cancer (Dupont et al. 1988, 1993a). In Japan, for 8424 cases of organ-confined or regional disease, initial treatment with CAB or castration alone was used in 39.9\% of patients, radical prostatectomy in $38.1 \%$, radiation therapy in $18.2 \%$, and watchful waiting in $4.7 \%$ of cases (Fujimoto et al. 2011). Among the patients with nonmetastatic disease, $65 \%$ received $\mathrm{CAB}$ while $25 \%$ received monotherapy with a GnRH agonist or surgical castration.

A survival advantage of prostate cancer patients treated with radiotherapy with a GnRH agonist for 3 years compared with radiotherapy alone has been observed (Bolla et al. 2009). More recently, a GnRH agonist treatment given before (neoadjuvant) and during radiotherapy has shown decreased prostate cancer mortality and increased overall survival (Jones et al. 2011). These data indicate that a better response to androgen blockade is observed if treatment, albeit being partial and suboptimal, is applied at a locally advanced stage. As mentioned earlier, no survival benefit has ever been observed with castration alone at the metastatic stage.

It is important to mention that if treatment is initiated immediately after diagnosis in patients with localized or locally advanced disease and is continued for at least 7 years without interruption, $\mathrm{CAB}$ can achieve long-term control or potentially cure prostate cancer in at least $90 \%$ of cases, as judged by no increase in serum prostate-specific antigen (PSA) within at least 5 years after stopping $\mathrm{CAB}$ administered up to 9 years previously (Labrie et al. 2002).

It is often erroneously mentioned that androgen blockade should not be administered early in prostate cancer because resistance to treatment is very likely to develop, thus 'saving' androgen blockade for use at a later stage of the disease. The fact that this belief is incorrect is proven by the observation that resistance to $C A B$ develops extremely rarely in patients with localized prostate cancer (Labrie et al. 2002, Akaza et al. 2006a, Ueno et al. 2006), while resistance to $\mathrm{CAB}$ develops in practically all patients having metastatic disease at the start of treatment. In fact, as mentioned above, resistance to $\mathrm{CAB}$ is a problem specific to metastatic disease and is a rare observation when $C A B$ is started at the localized stage.

\section{Castration-resistant prostate cancer}

The unavoidable reactivation or progression of prostate cancer in patients with metastatic disease originally treated by castration alone has, until recently, been considered androgen-independent or hormone-refractory prostate cancer. It has become clear, however, as suggested by the benefits observed after addition of flutamide to patients with prostate cancer progressing after castration (Labrie et al. 1988b) that the cancer progressing after castration remains androgen driven. More recently, these observations have been strongly revitalized, thus leading to the exciting development of MDV-3100 (Tran et al. 2009) and abiraterone (Attard et al. 2008) in CRPC patients.

\section{Mechanisms of resistance to castration}

The best scientifically supported mechanisms proposed to explain the response to further androgen blockade in CRPC patients are the local intraprostatic production of androgens, increased sensitivity to low androgens, AR amplification, splice variants, and mutations of AR leading to spontaneous AR activity or promiscuity with abnormal ligands (Labrie 2011a, Massard \& Fizazi 2011, Mostaghel \& Plymate 2011).

The human prostate contains the enzymes that convert DHEA into active androgens (Labrie et al. 1988a, El-Alfy et al. 1999, Nakamura et al. 2005, Luu-The et al. 2008, Pelletier 2008, Evaul et al. 2010). Although the serum levels of DHEA-S in the blood are much higher than those of DHEA, the intraprostatic concentrations of DHEA and DHEA-S are similar (Mohler et al. 2004). As mentioned above and as shown in Fig. 5C, intraprostatic DHT remains at sufficiently high levels to activate the AR following castration (Labrie et al. 1985, Bélanger et al. 1989, Mizokami et al. 2004, Nishiyama et al. 2004). Somewhat lower levels of intraprostatic DHT have been more recently measured after castration, but the authors always indicate the importance of the remaining DHT for continuous cancer progression after castration and the role of intracrine androgen formation (Titus et al. 2005, Page et al. 2006, Arai et al. 2011).

Prostate cancer progressing in castrated patients is dependent on the activation of AR by androgens (Chen et al. 2004, Mohler et al. 2004), as well demonstrated by the

Published by Bioscientifica Ltd 
response of CRPC by blockade of AR with the antiandrogen MDV-3100 which prevents DHT from binding to AR and its transfer to the nucleus where it can stimulate transcription of the androgen-responsive genes (Tran et al. 2009 ) and the inhibitor of $17 \alpha$-hydroxylase abiraterone (Attard et al. 2008). In most CRPC cases, the AR protein and AR-regulated genes are expressed, indicating that $\mathrm{AR}$ is still active and likely to be stimulating tumor growth (van der Kwast et al. 1991, Holzbeierlein et al. 2004, Scher \& Sawyers 2005, Yuan \& Balk 2009). In fact, AR is overexpressed in the majority of CRPC patients, thus potentially making prostate cancer cells hypersensitive to androgens (Linja et al. 2001). AR can also be mutated, thus causing AR to be activated by steroids other than testosterone and DHT (Taplin et al. 2003).

A suggested source of testosterone in CRPC is cholesterol (Twiddy et al. 2011). LNCaP cells have been reported to be able to transform radiolabeled cholesterol into testosterone in vitro and in vivo (Dillard et al. 2008, Locke et al. 2008, 2009). It has also been reported that CYP17A1 expression was increased in CRPC samples from patients treated with ketoconazole (Cai et al. 2011). It should be mentioned, however, that the mRNA levels of the steroidogenic enzymes required for complete de novo steroid synthesis from cholesterol are very low or absent in human prostate cancer cell lines and in the majority of clinical prostate cancer samples (Hofland et al. 2010) while the enzymes converting DHEA or 4-dione into androgens were elevated and even increased in CRPC patients (Stanbrough et al. 2006).

It is of interest that a correlation was found between the decline in serum PSA during androgen blockade and the initial intraprostatic androgen levels (Shibata et al. 2013). Both androgens, made locally from DHEA with a possible contribution of androgens made locally from cholesterol, can contribute to the intraprostatic androgens remaining after castration (Labrie et al. 1985, Mohler et al. 2004, Arnold et al. 2005, Stanbrough et al. 2006, Locke et al. 2008, Montgomery et al. 2008, Sharifi \& Auchus 2012).

Most importantly, the intraprostatic concentration of DHEA has been measured by liquid chromatography tandem mass spectrometry at values of the order of $30 \mathrm{ng} / \mathrm{g}$ tissue, with no change after castration/hormone therapy (Arai et al. 2011). These values of intraprostatic DHEA are five- to tenfold higher than the DHEA concentration in the blood (Labrie et al. 2009) and similar to the concentration of DHEA measured in benign and cancerous breast tissue in women (Poortman et al. 1983). Such data suggest that the presence of mechanisms permits DHEA transfer from the blood to the prostatic tissue, thus providing relatively high concentrations of intraprostatic DHEA available for transformation into testosterone and DHT by the intracrine mechanisms (Fig. 3).

The important clinical responses observed with the antiandrogen MDV-3100 and the 17 $\alpha$-hydroxylase inhibitor abiraterone are clear demonstrations of the importance of androgens made and acting in the prostate according to the mechanisms of intracrinology. The enzymatic conversion of DHEA to DHT has been shown to be essential for the activation of AR in LNCaP prostate cancer cells (Evaul et al. 2010), while in vitro studies have shown that prostate cancer stromal cells and human LNCaP prostatic cancer cells coordinate activation of AR via synthesis of testosterone and DHT from DHEA (Mizokami et al. 2009). In addition, increased expression of genes that code for the enzymes that convert DHEA into testosterone has been observed in CRPC (Stanbrough et al. 2006), while cancerous prostatic tissue can synthesize more DHT than does benign prostatic tissue (Nishiyama et al. 2007).

Interestingly, in this context, testosterone levels have been reported to be higher in metastases of prostate cancer from anorchid men than they are in primary cancers obtained from untreated eugonadal men (Mizokami et al. 2004). This finding could be explained by dysregulated expression of the genes that encode steroidogenic enzymes in cancer cells, a well-known phenomenon due to aberrant control of gene expression in cancer tissue. In addition to the local and autonomous synthesis of androgens, increased AR levels could explain the observation that androgen deprivation in prostate cancer xenograft models results in only transient cell cycle arrest (Agus et al. 1999). In fact, xenograft tumors show little evidence of apoptosis, and frequently grow rapidly, despite androgen deprivation. In preclinical models, overexpression of AR shortens the response duration and makes the tumors resistant to bicalutamide (Chen et al. 2004).

Sensitive liquid chromatography-tandem mass spectrometry has identified $5 \alpha$-dihydrodeoxy-corticosterone ( $5 \alpha$-OH-DOC) in prostate cancer tissue of CRPC patients, a compound which could activate $\mathrm{AR}$ and stimulate cancer cell growth (Uemura et al. 2010). On the other hand, by reducing intraprostatic androgens, abiraterone has been reported to induce the appearance of AR splice variants (Mostaghel et al. 2011) with the possibility of ligand-independent activation of AR (Mostaghel \& Plymate 2011).

Published by Bioscientifica Ltd. 
It is worth noting that low serum testosterone (Karamanolakis et al. 2006, Morgentaler \& Rhoden 2006) and intraprostatic DHT (Nishiyama et al. 2006) have been associated with increased risk of prostate cancer and higher Gleason score. Other studies have shown low serum testosterone to be associated with more aggressive disease (Ribeiro et al. 1997), more advanced stage at radical prostatectomy (Massengill et al. 2003, Isom-Batz et al. 2005), and higher grade cancer (Schatzl et al. 2001). In this context, it is possible that the partial $50-80 \%$ reduction in intraprostatic DHT observed following castration alone could trigger the same negative mechanisms, thus providing an explanation for the well recognized difficulty in treating CRPC. Such possibility can be supported by the findings of increased androgen biosynthesis accompanying low AR levels (McNamara et al. 2013).

It is of interest to mention that in the study of Nishiyama et al. (2006), the low intraprostatic DHT was not correlated with serum testosterone but with serum DHEA (Nishiyama et al. 2006), thus suggesting that intraprostatic DHT was modulated significantly by local intraprostatic formation of DHT from circulating DHEA by the intracrine mechanisms. Further support for the importance of extratesticular androgens is provided by the finding of a prostatic carcinoma in a patient 22 years after orchiectomy (Sharkey \& Fisher 1960).

Animal studies (Rosner et al. 1969) and human fetal studies (Voutilainen \& Miller 1986) indicate that DHEA and androgens are produced in nongonadal tissues other than the adrenal glands. Consequently, in analogy with other peripheral tissues, it is possible that DHEA could be synthesized from cholesterol to an unknown extent in the prostate (Mostaghel et al. 2012; Fig. 6). The potential local source of androgens possibly derived from cholesterol could be implicated, up to an unknown extent, in the development and progression of CRPC by acting directly on prostatic AR.

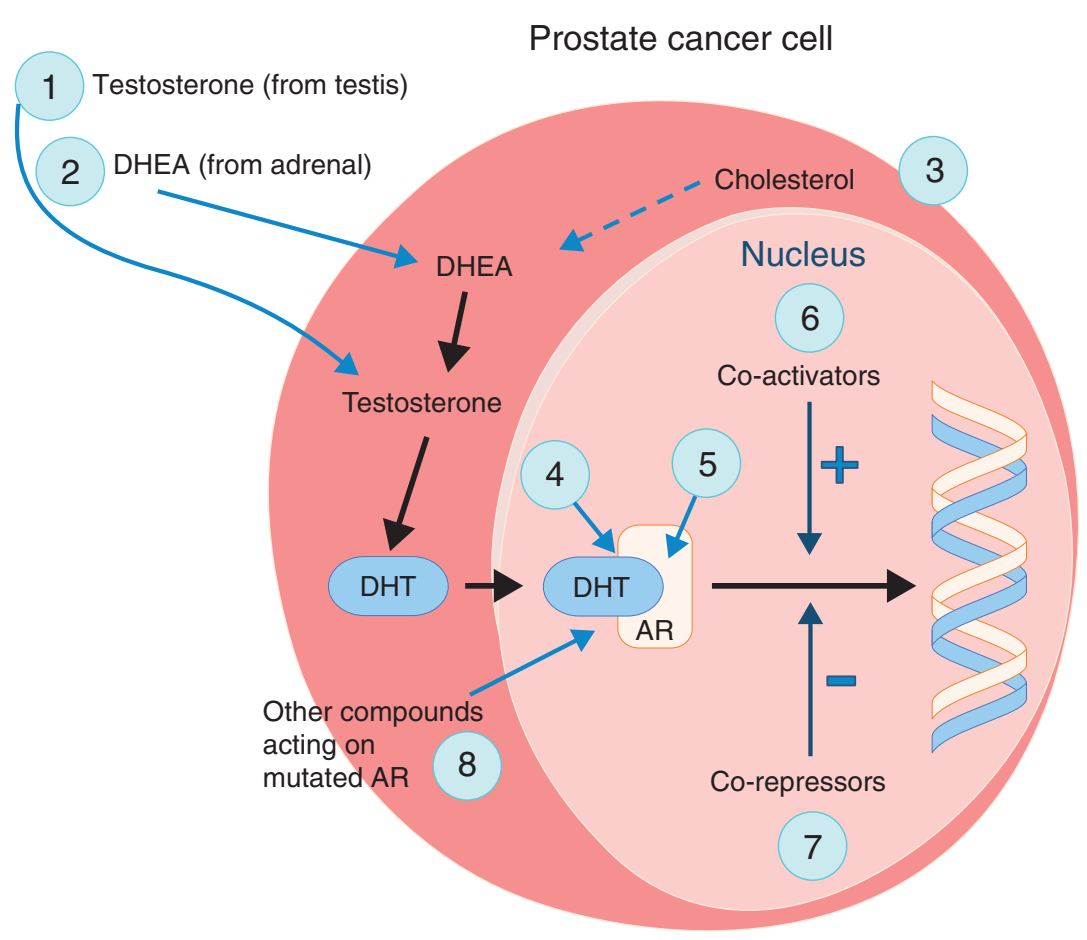

\section{Figure 6}

Potential sites of action for hormonal therapies in prostate cancer. On average, $60-75 \%$ of intraprostatic DHT is made from testosterone of testicular origin, highlighting the major importance of castration in the treatment of prostate cancer (1). The remaining intraprostatic DHT is made locally from the adrenal precursor DHEA (2). Some DHT could possibly be made locally from cholesterol (3). Accordingly, blocking the action of DHT made locally in the prostate after castration with a pure antiandrogen has an importance practically comparable with castration itself (4). In patients with CRPC, increased AR levels (5), mutated AR (5), and increased intraprostatic DHT formation $(2,3)$ seem to be implicated in disease progression. Potential changes in the normal equilibrium of the AR-ligandco-activators-co-repressors complex $(6,7)$ could also be involved. Mutated $A R$ could render some endogenous steroids stimulatory to AR action (8). $A R$, androgen receptor; CRPC, castration-resistant prostate cancer; $\mathrm{DHT}$, dihydrotestosterone. http://erc.endocrinology-journals.org DOI: 10.1530/ERC-13-0165
(C) 2014 Society for Endocrinology Printed in Great Britain 
Table 1 Castration-resistant prostate cancer treated with chemotherapy

\begin{tabular}{|c|c|c|c|c|}
\hline & $\begin{array}{l}\text { Overall } \\
\text { survival } \\
\text { (months) }\end{array}$ & $\begin{array}{l}\text { Hazard } \\
\text { ratio for } \\
\text { death }\end{array}$ & $\begin{array}{l}\text { Progression- } \\
\text { free survival } \\
\quad \text { (months) }\end{array}$ & $\begin{array}{c}\text { Hazard } \\
\text { ratio for } \\
\text { progression }\end{array}$ \\
\hline $\begin{array}{l}\text { Enzalutamide }^{a} \\
\text { vs placebo }\end{array}$ & 18.4 vs 13.6 & 0.63 & 8.3 vs 2.9 & 0.40 \\
\hline $\begin{array}{l}\text { Abiraterone }^{\mathrm{b}}+ \\
\text { prednisone vs } \\
\text { prednisone alone }\end{array}$ & 15.8 vs 11.2 & 0.74 & 5.6 vs 3.6 & 0.66 \\
\hline
\end{tabular}

\section{CAB in CRPC}

For patients with CRPC, the choice of treatments has been limited, although many responses were known to be obtained with further androgen blockade after castration (Labrie et al. 1985, 1988b, Small \& Vogelzang 1997).

As mentioned above, when androgen blockade is started at the metastatic stage, disease progression always occurs. Such resistance to treatment has generally been viewed as the end of the therapeutic role of androgen blockade. However, as mentioned earlier, early preclinical (Labrie \& Veilleux 1986) and clinical (Labrie et al. 1985, $1988 b$ ) data clearly indicated that responsiveness to androgens remains present at all stages of prostate cancer, thus providing an opportunity to develop effective hormonal therapies for these patients. In a series of nine studies carried out in patients progressing after castration (CRPC), a decrease in $50 \%$ of PSA or more was seen in 6-66\% of patients (Suzuki et al. 2010).

It is also of interest to mention that a large proportion of patients experience a paradoxical positive clinical response upon a simple arrest of antiandrogen administration or change in antiandrogen, with a decrease of $>90 \%$ in serum PSA in up to $47 \%$ of patients (Collinson et al. 1993, Dupont et al. 1993b, Kelly \& Scher 1993). Such data suggest that the ligand-specific changes in the 3D conformation of AR induced by each antiandrogen lead to preferential binding of different co-activators and co-repressors to AR, thus changing the activity of AR on transcription (Fig. 6).

\section{Abiraterone}

Abiraterone, by inhibiting the enzyme CYP17, decreases DHEA formation. It does also inhibit cortisol synthesis, thus stimulating ACTH secretion and adrenal mineralocorticoid secretion. The hypertension and hypokalemia secondary to excess mineralocorticoid secretion can be attenuated by the co-administration of glucocorticoids (ex: prednisone) which decrease ACTH secretion (de Bono et al. 2011).

In a multicenter phase III clinical trial in which CRPC patients showed progression after docetaxel chemotherapy, overall survival after a median follow-up of 20.2 months was 15.8 months in the abiraterone+prendnisone-treated group vs 11.2 months in the prednisone only group (Fizazi et al. 2012; Table 1). Mean radiologic progression-free survival was 5.6 vs 3.6 months for a hazard ratio of 0.66 in favor of abiraterone. For median time to PSA progression, values of 8.5 and 6.6 months were observed, for a hazard ratio of 0.63 in favor of abiraterone.

In CRPC patients not previously treated with chemotherapy, abiraterone + prednisone increased radiographic progression-free survival to 16.5 months compared with 8.3 months for the men receiving prednisone alone for a $47 \%$ reduction in the progression hazard after a median follow-up of 27.1 months (Ryan et al. 2013; Table 2). Median overall survival was 35.3 months in the abiraterone group compared with 30.1 months in the control group, thus representing a $21 \%$ improvement with a hazard ratio of 0.79 in favor of abiraterone (Table 2; Rathkopf \& Scher 2013). It can be mentioned that $69 \%$ of patients who received abiraterone + prednisone had at least a $50 \%$ decline in serum PSA compared with $29 \%$ with prednisone alone. Significant advantages were also observed of time to chemotherapy, opiate use, PSA progression, pain progression, and deterioration in health-related quality of life. The benefits observed with abiraterone in addition to the known effects of prednisone (Tannock et al. 2004, Sternberg et al. 2009) demonstrate the importance of extratesticular androgen biosynthesis and, consequently, the importance of CAB.

The most common adverse events accompanying abiraterone treatment are associated with increased mineralocorticoid secretion, namely hypokalemia,

Table 2 Castration-resistant prostate cancer not treated with chemotherapy

\begin{tabular}{|c|c|c|c|c|}
\hline & $\begin{array}{c}\text { Overall } \\
\text { survival } \\
\text { (months) }\end{array}$ & $\begin{array}{l}\text { Hazard } \\
\text { ratio for } \\
\text { death }\end{array}$ & $\begin{array}{l}\text { Progression- } \\
\text { free survival } \\
\text { (months) }\end{array}$ & $\begin{array}{c}\text { Hazard } \\
\text { ratio for } \\
\text { progression }\end{array}$ \\
\hline $\begin{array}{c}\text { Abiraterone }+ \\
\text { prednisone }\end{array}$ & 35.1 & 0.79 & 16.5 & 0.53 \\
\hline Prednisone & 30.1 & 0.79 & 8.3 & 0.53 \\
\hline
\end{tabular}

Ryan et al. (2013). Rathkopf \& Scher (2013).

Published by Bioscientifica Ltd. 
hypertension, and fluid retention, which are mitigated by concomitant prednisone administration (de Bono et al. 2011, Fizazi et al. 2012).

\section{Enzalutamide}

MDV-3100 (enzalutamide) is a novel antiandrogen with no agonistic activity (Tran et al. 2009, Jung et al. 2010). In 1199 CRPC patients having received chemotherapy with docetaxel, the median overall survival was 18.4 months in the group of men treated with enzalutamide $(160 \mathrm{mg} /$ day) compared with 13.6 months in men started on placebo, thus leading to a $37 \%$ decrease in the risk of death from any cause (Table 1 ). The hazard ratio for death after 520 deaths had occurred was 0.63 . The superiority of enzalutamide was also shown for all secondary endpoints: radiographic progression-free survival was reduced from 8.3 months in the placebo group to 2.9 months in patients treated with enzalutamide for a hazard ratio of 0.40 (Table 1). Similar effects were observed for time to PSA progression: 8.3 vs 3.0 months with a hazard ratio of 0.25. (Scher et al. 2012).

Convulsions are a dose-dependent toxic effect of enzalutamide at doses above the therapeutic range observed in animals (Foster et al. 2011). Seizures were reported in phase 1-2 clinical trials with enzalutamide beginning at doses of $360 \mathrm{mg}$ enzalutamide or more. Seizures were reported in $0.6 \%$ of patients in the phase III trial (Scher et al. 2012).

\section{Conclusions}

While more complete androgen blockade has been reported for quite some time to provide benefits in CRPC (Labrie et al. 1985, 1988a), the recent studies using the antiandrogen MDV-3100 (Tran et al. 2009, Scher et al. 2012) and abiraterone (Attard et al. 2008, de Bono et al. 2010, Fizazi et al. 2012) are the first placebo-controlled studies which provide a precise measure of the amplitude of the benefits achieved on progression-free survival and overall survival in CRPC. The addition of 4-5 months of overall survival obtained with MDV-3100 (Scher et al. 2012) and abiraterone (Fizazi et al. 2012) in CRPC patients confirms the central role of androgens and AR through all stages of prostate cancer. In fact, even after chemotherapy, the tumor progressing after castration is still dependent upon androgens and respond significantly to MDV-3100 and abiraterone. These crucial data stress the importance of targeting AR signaling as a key therapeutic target at all stages of prostate cancer, even in patients progressing following previous treatment with different androgen blockade manipulations.

\section{Future avenues of research and development in androgen blockade}

Future research on the physiological mechanisms of androgen biosynthesis, especially the local intracrine intraprostatic formation of androgens, is crucial in order to target with optimal precision each element involved in intraprostatic androgen formation (Fig. 6). The easy part of androgen blockade relates to the androgens of testicular origin which can be easily eliminated by medical (GnRH agonists or antagonists) or surgical castration. The much more difficult part relates to the control of the androgens made locally in the prostate by intracrine mechanisms.

Abiraterone has well demonstrated the importance of inhibiting androgen intraprostatic formation, while enzalutamide has shown the impact of blocking access to the AR following castration in progressing metastatic disease. The more potent and specific will be the inhibitors of androgen formation and action (anti-androgens), better should be the benefits of treatment. Priority should thus be devoted to the availability of well-tolerated and more potent inhibitors of steroidogenesis and more potent and exclusively antagonistic blockers of AR.

The data obtained with enzalutamide and abiraterone in patients with metastatic disease progressing after castration are playing a crucial role in our understanding of the intraprostatic formation of androgens (intracrinology) and provide the enthusiasm to move further. Accordingly, with today's knowledge, CAB should be given as first-line therapy in metastatic disease, or as early as possible before metastasis occurs. In fact, it seems clear that for prostate cancer, in analogy with any other type of cancer, the earlier the treatment, the higher should be its success with even the possibility of a cure in localized disease (Labrie et al. 2002, Akaza 2005).

Clinical research should therefore be directed to treatments applied at the localized stage of the disease when cure is a possibility (Labrie et al. 2002, Akaza 2005). In analogy with metastatic disease, it will then be important to use the most potent antiandrogens and/or inhibitors of androgen biosynthesis in order to reduce the duration of treatment required to obtain complete apoptosis or elimination of localized disease. It should be indicated that even with today's imperfect drugs, application of the knowledge gained with intracrinology (Labrie 1991) and the resulting development of CAB (Labrie et al. 1982, 1993, Crawford et al. 1989,

Published by Bioscientifica Ltd. 
Attard et al. 2008, Tran et al. 2009), elimination of death from prostate cancer is a possibility. More potent drugs should make this objective easier to achieve at an earlier stage of the disease.

\section{Declaration of interest}

The author declares that there is no conflict of interest that could be perceived as prejudicing the impartiality of the review.

\section{Funding}

This research did not receive any specific grant from any funding agency in the public, commercial or not-for-profit sector.

\section{References}

Agus DB, Cordon-Cardo C, Fox W, Drobnjak M, Koff A, Golde DW \& Scher HI 1999 Prostate cancer cell cycle regulators: response to androgen withdrawal and development of androgen independence. Journal of the National Cancer Institute 91 1869-1876.

Akaza H 2005 Effectiveness of Maximal Androgen Blockade (MAB): illusion or reality? Canadian Journal of Urology 12 (Suppl 1) 77-80.

Akaza H 2006 Trends in primary androgen depletion therapy for patients with localized and locally advanced prostate cancer: Japanese perspective. Cancer Science 97 243-247. (doi:10.1111/j.1349-7006. 2006.00180.x)

Akaza H 2008 Current status and prospects of androgen depletion therapy for prostate cancer. Best Practice \& Research. Clinical Endocrinology \& Metabolism 22 293-302. (doi:10.1016/j.beem.2008.01.010)

Akaza H, Yamaguchi A, Matsuda T, Igawa M, Kumon H, Soeda A, Arai Y, Usami M, Naito S, Kanetake H et al. 2004 Superior anti-tumor efficacy of bicalutamide $80 \mathrm{mg}$ in combination with a luteinizing hormonereleasing hormone (LHRH) agonist versus LHRH agonist monotherapy as first-line treatment for advanced prostate cancer: interim results of a randomized study in Japanese patients. Japanese Journal of Clinical Oncology 34 20-28. (doi:10.1093/jjco/hyh001)

Akaza H, Hinotsu S, Usami M, Ogawa O, Kagawa S, Kitamura T, Tsukamoto T, Naito S, Hirao Y, Murai M et al. 2006a The case for androgen deprivation as primary therapy for early stage disease: results from J-CaP and CaPSURE. Journal of Urology 176 S47-S49. (doi:10.1016/j.juro.2006. 06.070)

Akaza H, Homma Y, Usami M, Hirao Y, Tsushima T, Okada K, Yokoyama M, Ohashi Y \& Aso Y $2006 b$ Efficacy of primary hormone therapy for localized or locally advanced prostate cancer: results of a 10-year follow-up. BJU International 98 573-579. (doi:10.1111/j.1464-410X. 2006.06349.x)

Akaza H, Hinotsu S, Usami M, Arai Y, Kanetake H, Naito S \& Hirao Y 2009 Combined androgen blockade with bicalutamide for advanced prostate cancer: long-term follow-up of a phase 3, double-blind, randomized study for survival. Cancer 115 3437-3445. (doi:10.1002/cncr.24395)

Amoss M, Burgus R, Blackwell R, Vale W, Fellows R \& Guillemin R 1971 Purification, amino acid composition and N-terminus of the hypothalamic luteinizing hormone releasing factor (LRF) of ovine origin. Biochemical and Biophysical Research Communications 44 205-210.

Arai S, Miyashiro Y, Shibata Y, Tomaru Y, Kobayashi M, Honma S \& Suzuki K 2011 effect of castration monotherapy on the levels of adrenal androgens in cancerous prostatic tissues. Steroids 76 301-308. (doi:10.1016/j.steroids.2010.12.001)

Arnold JT, Le H, McFann KK \& Blackman MR 2005 Comparative effects of DHEA vs. testosterone, dihydrotestosterone, and estradiol on proliferation and gene expression in human LNCaP prostate cancer cells. American Journal of Physiology. Endocrinology and Metabolism 288 E573-E584. (doi:10.1152/ajpendo.00454.2004)

Arnst C 2003 Developments to watch. Why did prostate cancer death rates fall? Business Week 92.

Attard G, Reid AH, Yap TA, Raynaud F, Dowsett M, Settatree S, Barrett M, Parker C, Martins V, Folkerd E et al. 2008 Phase I clinical trial of a selective inhibitor of CYP17, abiraterone acetate, confirms that castration-resistant prostate cancer commonly remains hormone driven. Journal of Clinical Oncology 26 4563-4571. (doi:10.1200/JCO. 2007.15.9749)

Auclair C, Kelly PA, Coy DH, Schally AV \& Labrie F $1977 a$ Potent inhibitory activity of [D-Leu6, des-Gly-NH210] ethylamide on LH/hCG and PRL testicular receptor levels in the rat. Endocrinology 101 1890-1893. (doi:10.1210/endo-101-6-1890)

Auclair C, Kelly PA, Labrie F, Coy DH \& Schally AV 1977b Inhibition of testicular luteinizing receptor level by treatment with a potent luteinizing hormone-releasing hormone agonist of human chorionic gonadotropin. Biochemical and Biophysical Research Communications 76 855-862. (doi:10.1016/0006-291X(77)91579-0)

Baker ME 2004 Co-evolution of steroidogenic and steroid-inactivating enzymes and adrenal and sex steroid receptors. Molecular and Cellular Endocrinology 215 55-62. (doi:10.1016/j.mce.2003.11.007)

Bélanger B, Bélanger A, Labrie F, Dupont A, Cusan L \& Monfette G 1989 Comparison of residual C-19 steroids in plasma and prostatic tissue of human, rat and guinea pig after castration: unique importance of extratesticular androgens in men. Journal of Steroid Biochemistry 32 695-698. (doi:10.1016/0022-4731(89)90514-1)

Bélanger A, Pelletier G, Labrie F, Barbier O \& Chouinard S 2003 Inactivation of androgens by UDP-glucuronosyltransferase enzymes in humans. Trends in Endocrinology and Metabolism 14 473-479. (doi:10.1016/ j.tem.2003.10.005)

Bennett CL, Tosteson TD, Schmitt B, Weinberg PD, Ernstoff MS \& Ross SD 1999 Maximum androgen-blockade with medical or surgical castration in advanced prostate cancer: a meta-analysis of nine published randomized controlled trials and 4128 patients using flutamide. Prostate Cancer and Prostatic Diseases 2 4-8. (doi:10.1038/sj.pcan. 4500265)

Bolla M, de Reijke TM, Van Tienhoven G, Van den Bergh AC, Oddens J, Poortmans PM, Gez E, Kil P, Akdas A, Soete G et al. 2009 Duration of androgen suppression in the treatment of prostate cancer. New England Journal of Medicine 360 2516-2527. (doi:10.1056/ NEJMoa0810095)

de Bono JS, Oudard S, Ozguroglu M, Hansen S, Machiels JP, Kocak I, Gravis G, Bodrogi I, Mackenzie MJ, Shen L et al. 2010 Prednisone plus cabazitaxel or mitoxantrone for metastatic castration-resistant prostate cancer progressing after docetaxel treatment: a randomised open-label trial. Lancet 376 1147-1154. (doi:10.1016/S01406736(10)61389-X)

de Bono JS, Logothetis CJ, Molina A, Fizazi K, North S, Chu L, Chi KN, Jones RJ, Goodman OB Jr, Saad F et al. 2011 Abiraterone and increased survival in metastatic prostate cancer. New England Journal of Medicine 364 1995-2005. (doi:10.1056/NEJMoa1014618)

Cai C, Chen S, Ng P, Bubley GJ, Nelson PS, Mostaghel EA, Marck B, Matsumoto AM, Simon NI, Wang H et al. 2011 Intratumoral de novo steroid synthesis activates androgen receptor in castration-resistant prostate cancer and is upregulated by treatment with CYP17A1 inhibitors. Cancer Research 71 6503-6513. (doi:10.1158/00085472.CAN-11-0532)

Caubet JF, Tosteson TD, Dong EW, Naylon EM, Whiting GW, Ernstoff MS \& Ross SD 1997 Maximum androgen blockade in advanced prostate cancer: a meta-analysis of published randomized controlled trials using nonsteroidal antiandrogens. Urology 49 71-78. (doi:10.1016/S00904295(96)00325-1)

Chen CD, Welsbie DS, Tran C, Baek SH, Chen R, Vessella R, Rosenfeld MG \& Sawyers CL 2004 Molecular determinants of resistance to antiandrogen therapy. Nature Medicine 10 33-39. (doi:10.1038/nm972) http://erc.endocrinology-journals.org DOI: 10.1530/ERC-13-0165
(C) 2014 Society for Endocrinology Printed in Great Britain 
Collinson MP, Daniel F, Tyrrell CJ \& Teasdale C 1993 Response of carcinoma of the prostate to withdrawal of flutamide. British Journal of Urology 72 662-663. (doi:10.1111/j.1464-410X.1993.tb16234.x)

Crawford ED 2009 Understanding the epidemiology, natural history, and key pathways involved in prostate cancer. Urology 73 S4-S10. (doi:10.1016/j.urology.2009.03.001)

Crawford ED, Eisenberger MA, McLeod DG, Spaulding JT, Benson R, Dorr FA, Blumenstein BA, Davis MA \& Goodman PJ 1989 A controlled trial of leuprolide with and without flutamide in prostatic carcinoma. New England Journal of Medicine 321 419-424. (doi:10.1056/NEJM198908173210702)

Denis LJ, Keuppens F, Smith PH, Whelan P, Carneiro de Moura JL, Newling D, Bono A \& Sylvester R 1998 Maximal androgen blockade: final analysis of EORTC Phase III trial 30853. European Urology 33 144-151. (doi:10.1159/000019546)

Dillard PR, Lin MF \& Khan SA 2008 Androgen-independent prostate cancer cells acquire the complete steroidogenic potential of synthesizing testosterone from cholesterol. Molecular and Cellular Endocrinology 295 115-120. (doi:10.1016/j.mce.2008.08.013)

Dupont A, Labrie F, Giguere M, Borsanyi JP, Lacourciere Y, Bergeron N, Cusan L, Belanger A \& Emond J 1988 Combination therapy with flutamide and [D-Trp6]LHRH ethylamide for stage C prostatic carcinoma. European Journal of Cancer \& Clinical Oncology 24 659-666. (doi:10.1016/0277-5379(88)90296-9)

Dupont A, Cusan L, Gomez JL, Koutsilieris M, Suburu R, Emond J \& Labrie F $1993 a$ Combination therapy with flutamide and the LHRH agonist [D-Trp6-des-Gly-NH2]LHRH ethylamide in stage C prostatic carcinoma. British Journal of Urology 72 629-634. (doi:10.1111/j.1464-410X.1993. tb16223.x)

Dupont A, Gomez JL, Cusan L, Koutsilieris M \& Labrie F $1993 b$ Response to flutamide withdrawal in advanced prostate cancer in progression under combination therapy. Journal of Urology 150 908-913.

Egawa M, Misaki T, Imao T, Yokoyama O, Fuse H, Suzuki K \& Namiki M 2004 Retrospective study on stage B prostate cancer in the Hokuriku District, Japan. International Journal of Urology 11 304-309. (doi:10.1111/j.1442-2042.2004.00797.x)

Eisenberger MA \& Sinibaldi VW 2006 The role of cytotoxic chemotherapy in prostate cancer. A critical reevaluation 20 years later. Oncology 20 853-862 discussion 863, 867-868.

Eisenberger MA, Blumenstein BA, Crawford ED, Miller G, McLeod DG, Loehrer PJ, Wilding G, Sears K, Culkin DJ, Thompson IM et al. 1998 Bilateral orchiectomy with or without flutamide for metastatic prostate cancer. New England Journal of Medicine 339 1036-1042. (doi:10.1056/ NEJM199810083391504)

El-Alfy M, Luu-The V, Huang XF, Berger L, Labrie F \& Pelletier G 1999 Localization of type $517 \beta$-hydroxysteroid dehydrogenase, $3 \beta$-hydroxysteroid dehydrogenase and androgen receptor in the human prostate by in situ hybridization and immunocytochemistry. Endocrinology 140 1481-1491.

El Etreby MF, Habenicht UF, Louton T, Nishino Y \& Schroder HG 1987 Effect of cyproterone acetate in comparison to flutamide and megestrol acetate on the ventral prostate, seminal vesicle and adrenal glands of adult male rats. Prostate 11 361-374. (doi:10.1002/pros.2990110408)

Evaul K, Li R, Papari-Zareei M, Auchus RJ \& Sharifi N 2010 $3 \beta$-hydroxysteroid dehydrogenase is a possible pharmacological target in the treatment of castration-resistant prostate cancer. Endocrinology 151 3514-3520. (doi:10.1210/en.2010-0138)

Faure N, Labrie F, Lemay A, Bélanger A, Gourdeau Y, Laroche B \& Robert G 1982 Inhibition of serum androgen levels by chronic intranasal and subcutaneous administration of a potent luteinizing hormonereleasing hormone (GNRH) agonist in adult men. Fertility and Sterility 37 416-424.

Fizazi K, Scher HI, Molina A, Logothetis CJ, Chi KN, Jones RJ, Staffurth JN, North S, Vogelzang NJ, Saad F et al. 2012 Abiraterone acetate for treatment of metastatic castration-resistant prostate cancer: final overall survival analysis of the COU-AA-301 randomised, double-blind,

http://erc.endocrinology-journals.org DOI: 10.1530/ERC-13-0165
(C) 2014 Society for Endocrinology Printed in Great Britain placebo-controlled phase 3 study. Lancet Oncology 13 983-992. (doi:10.1016/S1470-2045(12)70379-0)

Foster WR, Car BD, Shi H, Levesque PC, Obermeier MT, Gan J, Arezzo JC, Powlin SS, Dinchuk JE, Balog A et al. 2011 Drug safety is a barrier to the discovery and development of new androgen receptor antagonists. Prostate 71 480-488. (doi:10.1002/pros.21263)

Fujimoto H, Nakanishi H, Miki T, Kubota Y, Takahashi S, Suzuki K, Kanayama HO, Mikami K \& Homma Y 2011 Oncological outcomes of the prostate cancer patients registered in 2004: report from the Cancer Registration Committee of the JUA. International Journal of Urology $\mathbf{1 8}$ 876-881. (doi:10.1111/j.1442-2042.2011.02895.x)

Furr BJ, Valcaccia B, Curry B, Woodburn JR, Chesterson G \& Tucker H 1987 ICI176,334: a novel nonsteroidal peripherally selective antiandrogen. Journal of Endocrinology 113 R7-R9. (doi:10.1677/joe.0.113R007)

Garcia JA \& Rini BI 2012 Castration-resistant prostate cancer: many treatments, many options, many challenges ahead. Cancer 118 2583-2593. (doi:10.1002/cncr.26582)

Hofland J, van Weerden WM, Dits NF, Steenbergen J, van Leenders GJ, Jenster G, Schroder FH \& de Jong FH 2010 Evidence of limited contributions for intratumoral steroidogenesis in prostate cancer. Cancer Research 70 1256-1264. (doi:10.1158/0008-5472.CAN-09-2092)

Holzbeierlein J, Lal P, LaTulippe E, Smith A, Satagopan J, Zhang L, Ryan C, Smith S, Scher H, Scardino P et al. 2004 Gene expression analysis of human prostate carcinoma during hormonal therapy identifies androgen-responsive genes and mechanisms of therapy resistance. American Journal of Pathology 164 217-227. (doi:10.1016/S00029440(10)63112-4)

Homma Y, Akaza H, Okada K, Yokoyama M, Usami M, Hirao Y, Tsushima T, Sakamoto A, Ohashi Y \& Aso Y 2004 Endocrine therapy with or without radical prostatectomy for T1b-T3NOM0 prostate cancer. International Journal of Urology 11 218-224. (doi:10.1111/j.1442-2042.2003.00781.x)

Huggins C \& Hodges CV 1941 Studies of prostatic cancer. I. Effect of castration, estrogen and androgen injections on serum phosphatases in metastatic carcinoma of the prostate. Cancer Research 1 293-297.

Isom-Batz G, Bianco FJ Jr, Kattan MW, Mulhall JP, Lilja H \& Eastham JA 2005 Testosterone as a predictor of pathological stage in clinically localized prostate cancer. Journal of Urology 173 1935-1937. (doi:10.1097/01.ju.0000158040.33531.e7)

Jemal A, Bray F, Center MM, Ferlay J, Ward E \& Forman D 2011 Global cancer statistics. CA: A Cancer Journal for Clinicians 61 69-90. (doi:10.3322/caac.20107)

Jones CU, Hunt D, McGowan DG, Amin MB, Chetner MP, Bruner DW, Leibenhaut MH, Husain SM, Rotman M, Souhami L et al. 2011 Radiotherapy and short-term androgen deprivation for localized prostate cancer. New England Journal of Medicine 365 107-118. (doi:10.1056/NEJMoa1012348)

Jung ME, Ouk S, Yoo D, Sawyers CL, Chen C, Tran C \& Wongvipat J 2010 Structure-activity relationship for thiohydantoin androgen receptor antagonists for castration-resistant prostate cancer (CRPC). Journal of Medicinal Chemistry 53 2779-2796. (doi:10.1021/jm901488g)

Kantoff PW, Higano CS, Shore ND, Berger ER, Small EJ, Penson DF, Redfern CH, Ferrari AC, Dreicer R, Sims RB et al. 2010 Sipuleucel-T immunotherapy for castration-resistant prostate cancer. New England Journal of Medicine 363 411-422. (doi:10.1056/NEJMoa1001294)

Karamanolakis D, Lambou T, Bogdanos J, Milathianakis C, Sourla A, Lembessis P, Halapas A, Pissimissis N, Dessypris N, Petridou ET et al. 2006 Serum testosterone: a potentially adjunct screening test for the assessment of the risk of prostate cancer among men with modestly elevated PSA values ( $>$ or $=3.0$ and $<10.0 \mathrm{ng} / \mathrm{ml}$ ). Anticancer Research 26 3159-3166.

Kelly WK \& Scher HI 1993 Prostate specific antigen decline after antiandrogen withdrawal: the flutamide withdrawal syndrome. Journal of Urology 149 607-609.

van der Kwast TH, Schalken J, Ruizeveld de Winter JA, van Vroonhoven CC, Mulder E, Boersma W \& Trapman J 1991 Androgen receptors in 
endocrine-therapy-resistant human prostate cancer. International Journal of Cancer 48 189-193. (doi:10.1002/ijc.2910480206)

Labrie F 1991 Intracrinology. Molecular and Cellular Endocrinology 78 C113-C118. (doi:10.1016/0303-7207(91)90116-A)

Labrie F 2007 Multiple intracrine hormonal targets in the prostate: opportunities and challenges. BJU International 100 48-51. (doi:10.1111/j.1464-410X.2007.06955.x)

Labrie F 2008 Endocrinology and the prostate. Preface. Best Practice \& Research. Clinical Endocrinology \& Metabolism 22 vii-vix. (doi:10.1016/ j.beem.2008.02.005)

Labrie F 2010 $a$ DHEA after menopause - sole source of sex steroids and potential sex steroid deficiency treatment. Menopause Management 19 $14-24$.

Labrie F $2010 b$ Hormonal therapy of prostate cancer. In Neuroendocrinology, The Normal Neuroendocrine System, Progress in Brain Research, pp 321341. Eds L Martini, Chrousos GP, Labrie F, Pacak K \& De Pfaff. Elsevier.

Labrie F 2011a Blockade of testicular and adrenal androgens in prostate cancer treatment. Nature Reviews. Urology 8 73-85. (doi:10.1038/nrurol. 2010.231)

Labrie F $2011 b$ Editorial: the major role of androgens in prostate cancer and the need for more efficient blockade. Expert Review of Endocrinology \& Metabolism 6 313-316. (doi:10.1586/eem.11.5)

Labrie F \& Labrie C 2013 DHEA and intracrinology at menopause, a positive choice for evolution of the human species. Climacteric 16 205-213. (doi:10.3109/13697137.2012.733983)

Labrie F \& Veilleux R 1986 A wide range of sensitivities to androgens develops in cloned Shionogi mouse mammary tumor cells. Prostate $\mathbf{8}$ 293-300. (doi:10.1002/pros.2990080309)

Labrie F, Bélanger A, Cusan L, Séguin C, Pelletier G, Kelly PA, Reeves JJ, Lefebvre FA, Lemay A \& Raynaud JP 1980 Antifertility effects of LHRH agonists in the male. Journal of Andrology 1 209-228.

Labrie F, Dupont A, Bélanger A, Cusan L, Lacourcière Y, Monfette G, Laberge JG, Emond J, Fazekas AT, Raynaud JP et al. 1982 New hormonal therapy in prostatic carcinoma: combined treatment with an LHRH agonist and an antiandrogen. Clinical and Investigative Medicine $\mathbf{5}$ 267-275.

Labrie F, Dupont A \& Bélanger A 1985 Complete androgen blockade for the treatment of prostate cancer. In Important Advances in Oncology, pp 193-217. Eds VT de Vita, S Hellman \& SA Rosenberg. Philadelphia: J.B. Lippincott.

Labrie C, Bélanger A \& Labrie F 1988a Androgenic activity of dehydroepiandrosterone and androstenedione in the rat ventral prostate. Endocrinology 123 1412-1417. (doi:10.1210/endo-123-3-1412)

Labrie F, Dupont A, Giguère M, Borsanyi JP, Lacourciere Y, Monfette G, Emond J \& Bergeron N 1988b Benefits of combination therapy with flutamide in patients relapsing after castration. British Journal of Urology 61 341-346. (doi:10.1111/j.1464-410X.1988.tb13971.x)

Labrie C, Simard J, Zhao HF, Bélanger A, Pelletier G \& Labrie F 1989 Stimulation of androgen-dependent gene expression by the adrenal precursors dehydroepiandrosterone and androstenedione in the rat ventral prostate. Endocrinology 124 2745-2754. (doi:10.1210/ endo-124-6-2745)

Labrie F, Dupont A, Cusan L, Gomez JL, Diamond P, Koutsilieris M, Suburu R, Fradet Y, Lemay M, Têtu B et al. 1993 Downstaging of localized prostate cancer by neoadjuvant therapy with flutamide and lupron: the first controlled and randomized trial. Clinical and Investigative Medicine 16 499-509.

Labrie F, Bélanger A, Cusan L, Simard J, Luu-The V, Labrie C, Gomez JL, Diamond P \& Candas B 1996 History of LHRH agonists and combination therapy in prostate cancer. Endocrine-Related Cancer 3 243-278. (doi:10.1677/erc.0.0030243)

Labrie F, Candas B, Gomez JL \& Cusan L 2002 Can combined androgen blockade provide long-term control or possible cure of localized prostate cancer? Urology 60 115-119. (doi:10.1016/S00904295(02)01639-4)
Labrie F, Bélanger A, Luu-The V, Labrie C, Simard J, Cusan L, Gomez JL \& Candas B 2005a Gonadotropin-releasing hormone agonists in the treatment of prostate cancer. Endocrine Reviews 26 361-379. (doi:10.1210/er.2004-0017)

Labrie F, Luu-The V, Bélanger A, Lin S-X, Simard J \& Labrie C 2005b Is DHEA a hormone? Starling review Journal of Endocrinology 187 169-196. (doi:10.1677/joe.1.06264)

Labrie F, Bélanger A, Bélanger P, Bérubé R, Martel C, Cusan L, Gomez JL, Candas B, Castiel I, Chaussade V et al. 2006 Androgen glucuronides, instead of testosterone, as the new markers of androgenic activity in women. Journal of Steroid Biochemistry and Molecular Biology 99 182-188. (doi:10.1016/j.jsbmb.2006.02.004)

Labrie F, Cusan L, Gomez JL, Martel C, Bérubé R, Bélanger P, Bélanger A, Vandenput L, Mellström D \& Ohlsson C 2009 Comparable amounts of sex steroids are made outside the gonads in men and women: strong lesson for hormone therapy of prostate and breast cancer. Journal of Steroid Biochemistry and Molecular Biology 113 52-56. (doi:10.1016/ j.jsbmb.2008.11.004)

Labrie F, Martel C \& Balser J 2011 Wide distribution of the serum dehydroepiandrosterone and sex steroid levels in postmenopausal women: role of the ovary? Menopause 18 30-43. (doi:10.1097/ gme.0b013e3181e195a6)

Levine GN, D'Amico AV, Berger P, Clark PE, Eckel RH, Keating NL, Milani RV, Sagalowsky AI, Smith MR \& Zakai N 2010 Androgendeprivation therapy in prostate cancer and cardiovascular risk: a science advisory from the American Heart Association, American Cancer Society, and American Urological Association: endorsed by the American Society for Radiation Oncology. Circulation 121 833-840. (doi:10.1161/CIRCULATIONAHA.109.192695)

Lichtenberg F 2002 Measuring the health impacts of medical innovation and expenditure. In Health Services Research Seminal Series 2002-2003. University of Minnesota, Minneapolis, MN, USA.

Linja MJ, Savinainen KJ, Saramaki OR, Tammela TL, Vessella RL \& Visakorpi T 2001 Amplification and overexpression of androgen receptor gene in hormone-refractory prostate cancer. Cancer Research $613550-3555$.

Locke JA, Guns ES, Lubik AA, Adomat HH, Hendy SC, Wood CA, Ettinger SL, Gleave ME \& Nelson CC 2008 Androgen levels increase by intratumoral de novo steroidogenesis during progression of castration-resistant prostate cancer. Cancer Research 68 6407-6415. (doi:10.1158/0008-5472.CAN-07-5997)

Locke JA, Nelson CC, Adomat HH, Hendy SC, Gleave ME \& Guns ES 2009 Steroidogenesis inhibitors alter but do not eliminate androgen synthesis mechanisms during progression to castration-resistance in LNCaP prostate xenografts. Journal of Steroid Biochemistry and Molecular Biology 115 126-136. (doi:10.1016/j.jsbmb.2009.03.011)

Luu-The V 2011 Assessment of steroidogenic pathways that do not require testosterone as intermediate. Hormone Molecular Biology and Clinical Investigation 5 161-165. (doi:10.1515/HMBCI.2011.007)

Luu-The V, Bélanger A \& Labrie F 2008 Androgen biosynthetic pathways in the human prostate. Best Practice \& Research. Clinical Endocrinology \& Metabolism 22 207-221. (doi:10.1016/j.beem.2008.01.008)

Massard C \& Fizazi K 2011 Targeting continued androgen receptor signaling in prostate cancer. Clinical Cancer Research 17 3876-3883. (doi:10.1158/1078-0432.CCR-10-2815)

Massengill JC, Sun L, Moul JW, Wu H, McLeod DG, Amling C, Lance R, Foley J, Sexton W, Kusuda L et al. 2003 Pretreatment total testosterone level predicts pathological stage in patients with localized prostate cancer treated with radical prostatectomy. Journal of Urology 169 1670-1675. (doi:10.1097/01.ju.0000062674.43964.d0)

McNamara KM, Nakamura Y, Sasano H, Handelsman DJ \& Simanainen U 2013 Prostate epithelial AR inactivation leads to increased intraprostatic androgen synthesis. Prostate 73 316-327. (doi:10.1002/ pros.22570)

Mizokami A, Koh E, Fujita H, Maeda Y, Egawa M, Koshida K, Honma S, Keller ET \& Namiki M 2004 The adrenal androgen androstenediol is

Published by Bioscientifica Ltd. 
present in prostate cancer tissue after androgen deprivation therapy and activates mutated androgen receptor. Cancer Research 64 765-771. (doi:10.1158/0008-5472.CAN-03-0130)

Mizokami A, Koh E, Izumi K, Narimoto K, Takeda M, Honma S, Dai J, Keller ET \& Namiki M 2009 Prostate cancer stromal cells and LNCaP cells coordinately activate the androgen receptor through synthesis of testosterone and dihydrotestosterone from dehydroepiandrosterone. Endocrine-Related Cancer 16 1139-1155. (doi:10.1677/ERC-09-0070)

Mohler JL, Gregory CW, Ford OH III, Kim D, Weaver CM, Petrusz P, Wilson EM \& French FS 2004 The androgen axis in recurrent prostate cancer. Clinical Cancer Research 10 440-448. (doi:10.1158/1078-0432. CCR-1146-03)

Montgomery RB, Mostaghel EA, Vessella R, Hess DL, Kalhorn TF, Higano CS, True LD \& Nelson PS 2008 Maintenance of intratumoral androgens in metastatic prostate cancer: a mechanism for castrationresistant tumor growth. Cancer Research 68 4447-4454. (doi:10.1158/ 0008-5472.CAN-08-0249)

Morgentaler A \& Rhoden EL 2006 Prevalence of prostate cancer among hypogonadal men with prostate-specific antigen levels of $4.0 \mathrm{ng} / \mathrm{mL}$ or less. Urology 68 1263-1267. (doi:10.1016/j.urology.2006.08.1058)

Mostaghel EA \& Plymate S 2011 New hormonal therapies for castrationresistant prostate cancer. Endocrinology and Metabolism Clinics of North America 40 625-642, x. (doi:10.1016/j.ecl.2011.05.013)

Mostaghel EA, Page ST, Lin DW, Fazli L, Coleman IM, True LD, Knudsen B, Hess DL, Nelson CC, Matsumoto AM et al. 2007 Intraprostatic androgens and androgen-regulated gene expression persist after testosterone suppression: therapeutic implications for castrationresistant prostate cancer. Cancer Research 67 5033-5041. (doi:10.1158/ 0008-5472.CAN-06-3332)

Mostaghel EA, Marck BT, Plymate SR, Vessella RL, Balk S, Matsumoto AM, Nelson PS \& Montgomery RB 2011 Resistance to CYP17A1 inhibition with abiraterone in castration-resistant prostate cancer: induction of steroidogenesis and androgen receptor splice variants. Clinical Cancer Research 17 5913-5925.

Mostaghel EA, Solomon KR, Pelton K, Freeman MR \& Montgomery RB 2012 Impact of circulating cholesterol levels on growth and intratumoral androgen concentration of prostate tumors. PLoS ONE 7 e30062. (doi:10.1371/journal.pone.0030062)

Nakamura Y, Suzuki T, Nakabayashi M, Endoh M, Sakamoto K, Mikami Y, Moriya T, Ito A, Takahashi S, Yamada S et al. 2005 In situ androgen producing enzymes in human prostate cancer. Endocrine-Related Cancer 12 101-107. (doi:10.1677/erc.1.00914)

Namiki M, Kitagawa Y, Mizokami A \& Koh E 2008 Primary combined androgen blockade in localized disease and its mechanism. Best Practice \& Research. Clinical Endocrinology \& Metabolism 22 303-315. (doi:10.1016/j.beem.2008.01.007)

Neri R, Monahan MD, Meyer JG, Afonso BA \& Tabachnick IA 1967 Biological studies of an antiandrogen (SH-714). European Journal of Pharmacology 1 438-444. (doi:10.1016/0014-2999(67)90107-0)

Nishiyama T, Hashimoto Y \& Takahashi K 2004 The influence of androgen deprivation therapy on dihydrotestosterone levels in the prostatic tissue of patients with prostate cancer. Clinical Cancer Research $\mathbf{1 0}$ 7121-7126. (doi:10.1158/1078-0432.CCR-04-0913)

Nishiyama T, Ikarashi T, Hashimoto Y, Suzuki K \& Takahashi K 2006 Association between the dihydrotestosterone level in the prostate and prostate cancer aggressiveness using the Gleason score. Journal of Urology 176 1387-1391. (doi:10.1016/j.juro.2006.06.066)

Nishiyama T, Ikarashi T, Hashimoto Y, Wako K \& Takahashi K 2007 The change in the dihydrotestosterone level in the prostate before and after androgen deprivation therapy in connection with prostate cancer aggressiveness using the Gleason score. Journal of Urology 178 1282-1288 discussion 1288-1289. (doi:10.1016/j.juro.2007.05.138)

Olsson M, Ekstrom L, Schulze J, Kjellman A, Akre O, Rane A \& Gustafsson O 2010 Radical prostatectomy: influence on serum and urinary androgen levels. Prostate 70 200-205.
Page ST, Lin DW, Mostaghel EA, Hess DL, True LD, Amory JK, Nelson PS, Matsumoto AM \& Bremner WJ 2006 Persistent intraprostatic androgen concentrations after medical castration in healthy men. Journal of Clinical Endocrinology and Metabolism 91 3850-3856. (doi:10.1210/ jc.2006-0968)

Pelletier G 2008 Expression of steroidogenic enzymes and sex-steroid receptors in human prostate. Best Practice \& Research. Clinical Endocrinology \& Metabolism 22 223-228. (doi:10.1016/j.beem. 2008.02.004)

Pelletier G, Cusan L, Auclair C, Kelly PA, Désy L \& Labrie F 1978 Inhibition of spermatogenesis in the rat by treatment with [D-Ala6, des-GlyNH210]LHRH ethylamide. Endocrinology 103 641-643. (doi:10.1210/ endo-103-2-641)

Peto R \& Dalesio O 2003 Breast and prostate cancer: 10-year survival gains in the hormonal adjuvant treatment trials. Abstract 328 presented at ECCO 12, Copenhagen, Denmark. European Journal of Cancer. Supplements 1 S101. (doi:10.1016/S1359-6349(03)90361-2)

Poortman J, Thijssen JH, von Landeghem AA, Wiegerinck MA \& Alsbach GP 1983 Subcellular distribution of androgens and oestrogens in target tissue. Journal of Steroid Biochemistry 19 939-945. (doi:10.1016/ 0022-4731(83)90037-7)

Prostate Cancer Triallists' Collaborative Group 2000 Maximum androgen blockade in advanced prostate cancer: an overview of the randomised trials. Lancet 355 1491-1498. (doi:10.1016/S01406736(00)02163-2)

Rathkopf D \& Scher HI 2013 Androgen receptor antagonists in castrationresistant prostate cancer. Cancer Journal 19 43-49. (doi:10.1097/PPO. Ob013e318282635a)

Ribeiro M, Ruff P \& Falkson G 1997 Low serum testosterone and a younger age predict for a poor outcome in metastatic prostate cancer. American Journal of Clinical Oncology 20 605-608. (doi:10.1097/00000421199712000-00015)

Rosner JM, Macome JC \& Cardinali DP 1969 In vitro biosynthesis of sterols and steroids by rat submaxillary glands. Endocrinology 85 1000-1003. (doi:10.1210/endo-85-6-1000)

Ryan CJ, Smith MR, de Bono JS, Molina A, Logothetis CJ, de Souza P, Fizazi K, Mainwaring P, Piulats JM, Ng S et al. 2013 Abiraterone in metastatic prostate cancer without previous chemotherapy. New England Journal of Medicine 368 138-148. (doi:10.1056/ NEJMoa1209096)

Schally AV, Arimura A, Baba Y, Naur RM, Matsuo H, Redding TW, Debelijuk L \& White WF 1971 Isolation and properties of FSH and LH-releasing hormone. Biochemical and Biophysical Research Communications 43 393-399.

Schatzl G, Madersbacher S, Thurridl T, Waldmuller J, Kramer G, Haitel A \& Marberger M 2001 High-grade prostate cancer is associated with low serum testosterone levels. Prostate 47 52-58. (doi:10.1002/pros.1046)

Scher HI \& Sawyers CL 2005 Biology of progressive, castration-resistant prostate cancer: directed therapies targeting the androgen-receptor signaling axis. Journal of Clinical Oncology 23 8253-8261. (doi:10.1200/ JCO.2005.03.4777)

Scher HI, Fizazi K, Saad F, Taplin ME, Sternberg CN, Miller K, de Wit R, Mulders P, Chi KN, Shore ND et al. 2012 Increased survival with enzalutamide in prostate cancer after chemotherapy. New England Journal of Medicine 367 1187-1197. (doi:10.1056/NEJMoa1207506)

Sharifi N \& Auchus RJ 2012 Steroid biosynthesis and prostate cancer. Steroids 77 719-726. (doi:10.1016/j.steroids.2012.03.015)

Sharkey DA \& Fisher ER 1960 Carcinoma of the prostate in the absence of testicular tissue. Journal of Urology 83 468-470.

Shibata Y, Suzuki K, Arai S, Miyoshi Y, Umemoto S, Masumori N, Kamiya N, Ichikawa T, Kitagawa Y, Mizokami A et al. 2013 Impact of pre-treatment prostate tissue androgen content on the prediction of castrationresistant prostate cancer development in patients treated with primary androgen deprivation therapy. Andrology 1 505-511. (doi:10.1111/ j.2047-2927.2013.00068.x) 
Siegel R, Naishadham D \& Jemal A 2013 Cancer statistics, 2013. CA: A Cancer Journal for Clinicians 63 11-30. (doi:10.3322/caac.21166)

Small EJ \& Vogelzang NJ 1997 Second-line therapy for advanced prostate cancer: a shifting paradigm. Journal of Clinical Oncology 15 382-388.

Stanbrough M, Bubley GJ, Ross K, Golub TR, Rubin MA, Penning TM, Febbo PG \& Balk SP 2006 Increased expression of genes converting adrenal androgens to testosterone in androgen-independent prostate cancer. Cancer Research 66 2815-2825. (doi:10.1158/00085472.CAN-05-4000)

St-Arnaud R, Lachance R, Kelly SJ, Belanger A, Dupont A \& Labrie F 1986 Loss of luteinizing hormone bioactivity in patients with prostatic cancer treated with an LHRH agonist and a pure antiandrogen. Clinical Endocrinology 24 21-30. (doi:10.1111/j.1365-2265.1986.tb03250.x)

Sternberg CN, Petrylak DP, Sartor O, Witjes JA, Demkow T, Ferrero JM, Eymard JC, Falcon S, Calabro F, James N et al. 2009 Multinational, double-blind, phase III study of prednisone and either satraplatin or placebo in patients with castrate-refractory prostate cancer progressing after prior chemotherapy: the SPARC trial. Journal of Clinical Oncology 27 5431-5438. (doi:10.1200/JCO.2008.20.1228)

Suzuki H, Hinotsu S, Akaza H, Fujii Y, Kawakami S, Kihara K, Akakura K, Suzuki M, Kitamura T, Homma Y et al. 2010 Hormonal therapy for prostate cancer: current topics and future perspectives. International Journal of Urology 17 302-313. (doi:10.1111/j.1442-2042.2010.02460.x)

Tannock IF, de Wit R, Berry WR, Horti J, Pluzanska A, Chi KN, Oudard S, Theodore C, James ND, Turesson I et al. 2004 Docetaxel plus prednisone or mitoxantrone plus prednisone for advanced prostate cancer. New England Journal of Medicine 351 1502-1512. (doi:10.1056/ NEJMoa040720)

Taplin ME, Rajeshkumar B, Halabi S, Werner CP, Woda BA, Picus J, Stadler W, Hayes DF, Kantoff PW, Vogelzang NJ et al. 2003 Androgen receptor mutations in androgen-independent prostate cancer: Cancer and Leukemia Group B Study 9663. Journal of Clinical Oncology 21 2673-2678. (doi:10.1200/JCO.2003.11.102)
Titus MA, Schell MJ, Lih FB, Tomer KB \& Mohler JL 2005 Testosterone and dihydrotestosterone tissue levels in recurrent prostate cancer. Clinical Cancer Research 11 4653-4657. (doi:10.1158/1078-0432.CCR-05-0525)

Tran C, Ouk S, Clegg NJ, Chen Y, Watson PA, Arora V, Wongvipat J, Smith-Jones PM, Yoo D, Kwon A et al. 2009 Development of a secondgeneration antiandrogen for treatment of advanced prostate cancer. Science 324 787-790. (doi:10.1126/science.1168175)

Twiddy AL, Leon CG \& Wasan KM 2011 Cholesterol as a potential target for castration-resistant prostate cancer. Pharmaceutical Research 28 423-437. (doi:10.1007/s11095-010-0210-y)

Uemura M, Honma S, Chung S, Takata R, Furihata M, Nishimura K, Nonomura N, Nasu Y, Miki T, Shuin T et al. $20105 \alpha$ DH-DOC ( $5 \alpha$-dihydro-deoxycorticosterone) activates androgen receptor in castration-resistant prostate cancer. Cancer Science 101 1897-1904. (doi:10.1111/j.1349-7006.2010.01620.x)

Ueno S, Namiki M, Fukagai T, Ehara H, Usami M \& Akaza H 2006 Efficacy of primary hormonal therapy for patients with localized and locally advanced prostate cancer: a retrospective multicenter study. International Journal of Urology 13 1494-1500. (doi:10.1111/j.14422042.2006.01604.x)

Voutilainen R \& Miller WL 1986 Developmental expression of genes for the stereoidogenic enzymes P450scc (20,22-desmolase), P450c17 (17 $\alpha$-hydroxylase/17,20-lyase), and P450c21 (21-hydroxylase) in the human fetus. Journal of Clinical Endocrinology and Metabolism 63 1145-1150. (doi:10.1210/jcem-63-5-1145)

Yoon FH, Gardner SL, Danjoux C, Morton G, Cheung P \& Choo R 2008 Testosterone recovery after prolonged androgen suppression in patients with prostate cancer. Journal of Urology 180 1438-1443 discussion 1443-1444. (doi:10.1016/j.juro.2008.06.029)

Yuan X \& Balk SP 2009 Mechanisms mediating androgen receptor reactivation after castration. Urologic Oncology 27 36-41. (doi:10.1016/ j.urolonc.2008.03.021)

Received in final form 6 May 2014

Accepted 9 May 2014

Made available online as an Accepted Preprint

13 May 2014
(C) 2014 Society for Endocrinology Printed in Great Britain 